\title{
MEDIA KOMUNIKASI VISUAL TERHADAP HASIL BELAJAR KETERAMPILAN BERBICARA PADA MATA PELAJARAN AQIDAH DAN AKHLAK DI MADRASAH IBTIDAYAH NEGERI 2 MAKASSAR
}

\author{
Darmawati, Nursyaida \\ ${ }^{1,2}$ Prodi Pendidikan Guru Sekolah Dasar, Fakultas Keguruan dan Ilmu Pendidikan, \\ Universitas Pahuwato Gorontalo, Indonesia
}

Korespondensi.E-mail: darmawati@unipo.ac.id

\begin{abstract}
Abstrak
Tujuan dari penelitian ini untuk mengetahui pengaruh penggunaan media komunikasi terhadap hasil belajar keterampilan berbicara pada mata pelajaran Aqidah Dan Akhlak siswa kelas IV Sekolah Madrasah Ibtidayah Negeri 2 Makassar.Media yang digunakan dalam penelitian ini media komunikasi visual. Hasil penelitian membuktikan bahwa pengaruh penggunaan media komunikasi visual terhadap hasil belajar keterampilan berbicara pada mata pelajaran Aqidah Dan Akhlak siswa kelas IV Sekolah Madrasah Ibtidayah Negeri 2 Makassar telah diterima
\end{abstract}

Kata Kunci: Media; Komunikasi Visual; Keterampilan Berbicara

\section{VISUAL COMMUNICATION MEDIA TOWARDS RESULTS OF SKILLS SPEAKING ON AQIDAH AND AKHLAK LESSONS IN MADRASAH IBTIDAYAH NEGERI 2 MAKASSAR}

\begin{abstract}
The aim of this study is to determine the effect of the utilizingmedia of communication to the outcomes of learning speaking skills in subjects Aqidah and Morals of the fourth grade students at Madrasah School Ibtidayah Negeri 2 of Makassar. The Media is used to this research is visual communication media. The result of the research proves that the utilizingmedia of communication to the outcomes of learning speaking skills in subjects Aqidah and Morals of the fourth grade students at Madrasah School Ibtidayah Negeri 2 of Makassarhave been accepted.
\end{abstract}

Keywords: Media; Visual Communication;

\section{PENDAHULUAN}

Pendidikan merupakan modal dasar bagi manusia untuk menjadi insan yang berguna dan bermanfaat dalam segala aspek kehidupannya.Media adalah segala bentuk dan saluran yang digunakan untuk menyampaikan informasi atau pesan. Komunikasi adalah suatu proses dimana seseorang atau beberapa orang, kelompok, organisasi, dan masyarakat menciptakan, dan menggunakan informasi agar terhubung dengan lingkungan dan orang lain.

Copyright (C2020, JRPD, ISSN 2615 - 1723 (Print), ISSN 2615 - 1766 (Online) 


\section{Jurnal Riset Pendidikan Dasar, 03 (1), April 2020 (63-69)}

Darmawati, Nursyaida

Komunikasi visual adalah suatu proses penyampaian pesan dimana lambang-lambang yang dikirimkan komunikator hanya ditangkap oleh komunikan semata-mata hanya melalui indra penglihatan.

Media dominan dalam berkomunikasi merupakan jendela yang memungkinkan kita untuk dapat melihat lingkungan yang lebih jauh, sebagai penafsir yang membantu memahami pengalaman, sebagai landasan penyampai informasi, sebgai komunikasi interaktif yang meliputi opini audiens, sebagai penanda pemberi intruksi atau petunjuk, sebagai penyaring atau pembagi pengalaman dan focus terhadap orang lain, cermin yang merefleksikan diri kita dan penghalang yang menutupi kebenaran. Belajar adalah suatu proses kompleks yang terjadi pada semua orang yang berlangsung seumur hidup.

Masalah belajar adalah masalah adalah masalah bagi setiap manusia, dengan belajar manusia memperoleh keterampilan, kemampuan, sehingga terbentuklah sikap dan bertambahlah ilmu pengetahuan.Bahasa adalah bahasa melayu yang dijadikan sebagai bahasa resmi Republik Indonesia dalam bahasa persatuan bangsa Indonesia. Dalam implementasinya, pembelajaran Aqidah Dan Akhlak menggunakan pendekatan berbasis teks. Teks dapat berwujud teks tertulis maupun teks lisan.Teks merupakan ungkapan pikiran manusia yang lengkap yang didalamnya memiliki situasi dan konteks.

Berdasarkan uraian di atas rumusan masalah dalam penelitian ini adalah: "“Apakah ada pengaruh penggunaan media komunikasi visual terhadap hasill belajar keterampilan berbicara pada mata pelajaran Aqidah Dan Akhlak siswa kelas IV Sekolah Madrasah Ibtidayah Negeri 2 Makassar ? “. Tujuan penelitian ini adalah untuk mengetahui pengaruh penggunaan media komunikasi visual terhadap hasill belajar keterampilan berbicara pada mata pelajaran Aqidah Dan Akhlak siswa kelas IV Sekolah Madrasah Ibtidayah Negeri 2 Makassar

Komunikasi visual adalah suatu proses penyampaian pesan dimana lambang-lambang yang dikirimkan komunikator hanya ditangkap oleh komunikan semata-mata hanya melalui indra penglihatan. Bentuk komunikasi seperti ini bisa bersifat langsung (sebagaimana dua orang tuna rungu saling bercengkrama menggunakan bahasa isyarat), namun sebagian besar menggunakan media perantara yang lazim disebut media komunikasi visual.Komunikasi melalui penglihatan adalah sebuah rangkaian proses penyampaian infromasi atau pesan kepada pihak lain dengan penggunaan media penggambaran yang hanya terbaca oleh indera penglihatan. Komunikasi visual menkombinasikan seni, lambang, gambar, desain grafis, ilustrasi, dan warna dalam penyampaiannya.

Adapun fungsi dari berkomunikasi visual yaitu :

1. Sebagai sarana informasi dan instruksi, bertujuan menunjukkan hubungan antara suatu hal dengan hal yang lain dalam petunjuk, arah, posisi dan skala, contohnya peta, diagram, simbol dan penunjuk arah.

2. Sebagai sarana persentasi dan promosi untuk menyampaikan pesan, mendapatkan perhatian (atensi) dari mata (secara visual) dan membuat pesan tersebut dapat diingat; contohnya poster.

3. Sebagai sarana identifikasi, Identitas seseorang dapat mengatakan tentang siapa orang itu, atau dari mana asalnya.

Hasil belajar adalah kemampuankemampuan yang dimiliki siswa setelah ia menerima pengalaman belajarnya. Gagne menyatakan hasil belajar adalah kemampuan (performance) yang dapat teramati dalam diri seseorang dengan kapabilitas. Hasil belajar adalah perubahan perilaku yang berupa pengetahuan atau pemahaman, keterampilan dan sikap yang diperoleh siswa selama berlangsungnya proses belajar mengajar atau yang lazim disebut dengan pembelajaran.Jadi hasil belajar adalah perubahan perilaku atau kemampuan yang terjadi pada siswa setelah berlangsungnya proses belajar mengajar, yang dapat diamati yaitu berupa pengetahuan atau pemahaman, keterampilan, dan sikap.

Dalam penelitian ini, penilaian pada pelajaran Aqidah Dan Akhlak terbatasa hanya pada penilaian kognitif. Karena ranah kognitiflah yang paling banyak dinilai oleh para guru di sekolah karena berkaitan dengan kemampuan para siswa dalam menguasai isi bahan pelajaran.

Berbicara adalah suatu keterampilan berbahasa yang berkembang pada kehidupan anak yang didahului oleh keterampilan menyimak, pada masa tersebutlah kemampuan berbicara atau berujar dipelajari.Berbicara sudah barang tentu erat berhubungan dengan perkembangan kosa kata yang diperoleh anak melalui kagiatan menyimak dan membaca.Sebelum matang dalam perkembangan bahasa juga merupakan suatu keterlambatan dalam kegiatan berbahasa.

Copyright (C2020, JRPD, ISSN 2615 - 1723 (Print), ISSN 2615 - 1766 (Online) 
Tujuan berbicara, Setiap kegiatan yang dilakukan manusia memiliki maksud dan tujuan.Menurut Tarigan (2013:15) tujuan utama berbicara adalah untuk berkomunikasi. Agar dapat menyampaikan piiran secara efektif, maka sebaiknya sang pembicara memahami makna segala sesuatu yang ingin dikombinasikan, dia harus mampu memahami efek komunikasi terhadap pendengarannya, dan dia harus mengetahui prinsip-prinsip yang mendasari segala sesuatu situasi pembicaraan, baik secara umum maupun perorangan.

Berbicara atau kegiatan komunikasi lisan merupakan kegiatan individu dalam usaha menyampakan pesan secara lisan kepada sekelompok orang. Faktor yang dapat menunjang keefektifan berbicara adalah sebagai berikut :

1) Penguasaan bahasa

2) Keberanian dan ketenangan

3) Kesanggupan menyampaikan ide dengan lancar dan teratur.

Ada kalanya proses komunikasi mengalami gangguan yang mengakibatkan pesan yang diterima oleh pendengar tidak sama dengan apa yang dimaksudkan oleh pembicara. Faktor penyebab gangguan dalam kegiatan berbicara, yaitu :

1) Faktor fisik, yaitu faktor yang ada pada partisipan sendiri

2) Faktor media, yaitu faktor linguistik dan faktor non-linguistik, misalnya, lagu, irama, tekanan, ucapan, isyarat gerak bagian tubuh, dan

3) Faktor psikologis, kondisi kejiwaan partisipan komunikasi, misalnya dalam keadaan marah, menangis dan sakit.

\section{METODE}

Metode penelitian yang dilakukan dalam penelitian ini adalah metode pre-eksperimen. Menurut Sugiono (2019:109) "penelitian preeksperimen hasilnya merupakan variabel dependen bukan semata-mata dipengaruhi oleh variabel independen". Hal ini dapat terjadi karena tidak adanya variabel kontrol, dan sampel tidak dipilih secara random.

Desain penelitian ini merupakan rancangan bagaimana penelitian
dilaksanakan.Desain penelitian yang dilakukan dalam penelitian ini ialah one group pretest posttest design.Dalam desain ini, sebelum perlakuan diberikan terlebih dahulu sampel diberi posttest (tes akhir).Desain ini digunakan sesuai dengan tujuan yang hendak dicapai yaitu ingin mengetahui pengaruh penggunaan media komunikasi terhadap hasil belajar keterampilan berbicara siswa.Berikut merupakan tabel desain penelitian one group pretest posttest design.

\section{HASIL DAN PEMBAHASAN}

\section{Deskripsi Hasil Belajar sebelum digunakan Media Komunikasi Visual}

Berdasarkan hasil penelitian yang dilakukan oleh peneliti di Sekolah Madrasah Ibtidayah Negeri 2 Makassar mulai tanggal $10 \mathrm{Mei}$ 2018, maka diperoleh data-data yang dikumpulkan melalui instrument tes sehingga dapat diketahui hasil belajar keterampilan berbicara siswa berupa nilai dari kelas IV Sekolah Madrasah Ibtidayah Negeri 2 Makassar .

Untuk mencari mean (rata-rata) nilai pre-test murid kelas IV Sekolah Madrasah Ibtidayah Negeri 2 Makassar, dapat diketahui melalui rumus di bawah ini:

$$
\begin{aligned}
\mathrm{Me} & =\frac{\sum \mathrm{Xi}}{\mathrm{n}} \\
& =\frac{1.750}{28} \\
& =62,5
\end{aligned}
$$

Dari hasil perhitungan di atas, maka diperoleh nilai rata-rata dari hasil belajar siswa kelas IV Sekolah Madrasah Ibtidayah Negeri 2 Makassar, sebelum penggunaan media komunikasi visual yaitu 62,5.

Apabila nilai hasil pretest murid kelas IV Sekolah Madrasah Ibtidayah Negeri 2 Makassar, sebelum digunakan media komunikasi visualdikelompokkan dalam lima kategori, maka akan diperoleh distribusi dan presentase seperti pada Tabel .1

Tabel 1 Distribusi Frekuensi dan Persentase Skor Hasil Pretest

\begin{tabular}{rcccc}
\hline No & Interval & Kategori & Frekuensi & Persentase (\%) \\
\hline 1 & $0-54$ & Sangat Rendah & 6 & $21,43 \%$ \\
2 & $55-64$ & Rendah & 6 & $21,43 \%$ \\
\hline
\end{tabular}

Copyright C2020, JRPD, ISSN 2615 - 1723 (Print), ISSN 2615 - 1766 (Online) 
Jurnal Riset Pendidikan Dasar, 03 (1), April 2020 (63-69)

Darmawati, Nursyaida

\begin{tabular}{ccccc}
3 & $65-79$ & Sedang & 11 & $39,29 \%$ \\
4 & $80-89$ & Tinggi & 4 & $14,28 \%$ \\
5 & $90-100$ & Sangat Tinggi & 1 & $3.57 \%$ \\
\hline \multicolumn{7}{c}{ Jumlah } & 28 & $100 \%$ \\
\hline
\end{tabular}

Berdasarkan data yang dapat dilihat pada pada presentase 3,57\%. Melihat dari hasil tabel 1, maka dapat disimpulkan bahwa hasil presentase yang ada, dapat dikatakan bahwa belajar siswa pada tahap pretest dengan tingkat kemampuan siswa dalam memahami serta menggunakan instrument tes dikategorikan sangat penguasaan materi pelajaran Aqidah Dan rendah yaitu $21,43 \%$, rendah $21,43 \%$, sedang Akhlaksebelum digunakan media komunikasi $39,29 \%$, tinggi $14,28 \%$, dan sangat tinggi berada tergolong sangat rendah.

Tabel 2 Deskripsi Ketuntasan Hasil Pretest

\begin{tabular}{cccc}
\hline Skor & Kategorisasi & Frekuensi & Persentase (\%) \\
\hline $0-64$ & Tidak tuntas & 12 & $42,86 \%$ \\
$65-100$ & Tuntas & 16 & $57,14 \%$ \\
\hline \multicolumn{2}{c}{ Jumlah } & 28 & $100 \%$ \\
\hline
\end{tabular}

Dari Tabel 2 di atas terlihat bahwa siswa yang tidak tuntas sebanyak 12 orang (42.86\%) dan 17 orang $(57.14 \%)$ siswa yang termasuk dalam kategori tuntas, sehingga dapat disimpulkan bahwa hasil belajar Aqidah Dan Akhlak kelas IV Sekolah Madrasah Ibtidayah Negeri 2 Makassar sebelum digunakan media komunikasi tergolong sangat rendah.

Deskripsi Hasil Belajar (Posttest) Aqidah Dan Akhlak setelah digunakan Media Komunikasi

Selama penelitian berlangsung, terjadi perubahan terhadap hasil belajar Siswa kelas IV Sekolah Madrasah Ibtidayah Negeri 2 Makassar setelah diberikan perlakuan.

Untuk mencari mean (rata-rata) nilai post-test dari siswa kelas IV Sekolah Madrasah Ibtidayah Negeri 2 Makassar, dapat diketahui bahwa nilai dari $\sum f x=2.175$ dan nilai dari $\mathrm{N}$ sendiri adalah 28 . $\mathrm{Me}=\frac{\sum \mathrm{Xi}}{\mathrm{n}}$

$$
\begin{aligned}
& =\frac{2.175}{28} \\
=77,69 &
\end{aligned}
$$

Dari hasil perhitungan di atas maka diperoleh nilai rata-rata dari hasil belajar siswa kelas IV Sekolah Madrasah Ibtidayah Negeri 2 Makassar setelah penggunaan media komunikasi yaitu 77 dari skor ideal 100.

Apabila nilai hasil post-test murid kelas IV Sekolah Madrasah Ibtidayah Negeri 2 Makassar setelah digunakan media komunikasi dikelompokkan dalam lima kategori, maka akan diperoleh distribusi dan presentase seperti pada Tabel 3.

Kemudian dapat diperoleh nilai rata-rata (mean) sebagai berikut:

Tabel 3 Deskripsi Frekuensi Dan Persentase Skor Hasil Post-test

\begin{tabular}{ccccc}
\hline No & Interval & Kategori & Frekuensi & Persentase (\%) \\
\hline 1 & $0-54$ & Sangat Rendah & - & - \\
2 & $55-64$ & Rendah & 2 & $7,14 \%$ \\
3 & $65-79$ & Sedang & 11 & $39,29 \%$ \\
4 & $80-89$ & Tinggi & 9 & $32,14 \%$ \\
5 & $90-100$ & Sangat Tinggi & 6 & $21,43 \%$ \\
\hline \multicolumn{2}{r}{ Jumlah } & & 28 & $100 \%$
\end{tabular}

Berdasarkan data yang dapat dilihat pada

tabel 3, maka dapat disimpulkan bahwa hasil belajar siswa pada tahap post-test dengan menggunakan instrument test dikategorikan sangat tinggi yaitu $21,43 \%$, tinggi $32,14 \%$, sedang $39,29 \%$, presentase $0 \%$. Melihat dari hasil presentase yang ada, dapat dikatakan bahwa tingkat kemampuan siswa dalam memahami serta menguasai materi pelajaran Aqidah Dan Akhlak setelah menggunakan media komunikasi tergolong tinggi. rendah $7,14 \%$ dan sangat rendah berada pada

Tabel 4 Deskripsi Ketuntasan Hasil Belajar post-test

\begin{tabular}{cccc}
\hline Skor & Kategorisasi & Frekuensi & Persentase (\%) \\
\hline $0-64$ & Tidak Tuntas & 2 & $7,14 \%$
\end{tabular}

Copyright (C2020, JRPD, ISSN 2615 - 1723 (Print), ISSN 2615 - 1766 (Online) 
Jurnal Riset Pendidikan Dasar, 03 (1), April 2020 (63-69)

Darmawati, Nursyaida

\begin{tabular}{cccc}
$65-100$ & Tuntas & 26 & $92,86 \%$ \\
\hline Jumlah & 28 & $100 \%$ \\
\hline
\end{tabular}

Dari Tabel 4 di atas, terlihat bahwa masih ada 2 orang $(7,14 \%)$ siswa yang tidak tuntas dan sebanyak 26 orang $(92,86 \%)$ yang memenuhi kriteria ketuntasan Minimal, sehingga dapat disimpulkan bahwa hasil belajar Ilmu Pengetahuan Sosial murid kelas IV Sekolah Madrasah Ibtidayah Negeri 2 Makassar setelah digunakan media komunikasi tergolong tinggi.

Deskripsi Aktivitas siswa dalam pembelajaran Aqidah Dan Akhlak selama digunakan Media Komunikasi Visual

Hasil pengamatan aktivitas siswa dalam mengikuti pembelajaran dengan menggunakan media komunikasi selama 2 kali pertemuan dinyatakan dalam presentase sebagai berikut:

Tabel 5 Hasil Analisis Data Observasi Aktivitas Siswa

\begin{tabular}{|c|c|c|c|c|c|c|c|}
\hline \multirow{2}{*}{ No } & \multirow{2}{*}{ Komponen yang diamati } & \multicolumn{4}{|c|}{ Pertemuan Ke- } & \multirow{2}{*}{$\begin{array}{l}\text { Rata- } \\
\text { Rata }\end{array}$} & \multirow{2}{*}{$\begin{array}{l}\text { Persentase } \\
(\%)\end{array}$} \\
\hline & & I & II & III & IV & & \\
\hline 1 & $\begin{array}{l}\text { Murid yang hadir pada saat } \\
\text { kegiatan pembelajaran }\end{array}$ & & 28 & 28 & & 28 & $100 \%$ \\
\hline 2 & $\begin{array}{l}\text { Murid yang memperhatikan } \\
\text { pada saat guru menjelaskan } \\
\text { materi }\end{array}$ & $\mathbf{P}$ & 20 & 25 & $\mathbf{P}$ & 22,5 & $80,35 \%$ \\
\hline 3 & $\begin{array}{l}\text { Murid yang melakukan aktifitas } \\
\text { negatif selama proses } \\
\text { pembelajaran (main-main, ribut, } \\
\text { dll) }\end{array}$ & $\mathbf{E}$ & 2 & - & $\mathbf{O}$ & 1 & $3,57 \%$ \\
\hline 4 & $\begin{array}{l}\text { Murid yang bertanya tentang } \\
\text { materi yang belum dipahami }\end{array}$ & $\mathbf{T}$ & 20 & 22 & $\mathbf{T}$ & 21 & $75 \%$ \\
\hline 5 & $\begin{array}{l}\text { Murid yang bekerja sama dan } \\
\text { berpartisipasi dalam kelompok }\end{array}$ & $\mathbf{E}$ & 25 & 27 & & 26 & $92,85 \%$ \\
\hline 6 & $\begin{array}{l}\text { Keaktifan murid memberikan } \\
\text { tanggapan terhadap pertanyaan } \\
\text { guru }\end{array}$ & $\mathbf{S}$ & 19 & 20 & $\mathbf{T}$ & 19,5 & $69,64 \%$ \\
\hline 7 & 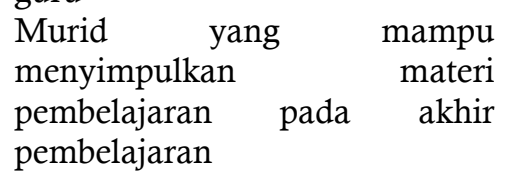 & $\mathrm{T}$ & 15 & 20 & $\mathbf{E}$ & 17,5 & $62,5 \%$ \\
\hline 8 & $\begin{array}{l}\text { Murid yang memanfaatkan } \\
\text { media secara langsung }\end{array}$ & & 18 & 25 & $\mathbf{T}$ & 21,5 & $76,78 \%$ \\
\hline
\end{tabular}
bahwa:
a. Persentase kehadiran siswa sebesar $100 \%$
b. Persentase siswa yang memperhatikan pada saat guru menjelaskan materi $80,35 \%$
c. Persentase siswa yang melakukan aktifitas negatif selama proses pembelajaran (main- main, ribut) $3,57 \%$

d. Persentase siswa yang bertanya tentang materi yang belum dipahami $75 \%$

e. Persentase siswa yang bekerja sama dan berpartisipasi dalam kelompok $92,85 \%$

f. Keaktifan siswa memberikan tanggapan terhadap pertanyaan guru 69,64\%

g. Persentase siswa yang mampu menyimpulkan materi pembelajaran pada akhir pembelajaran $62,5 \%$ bahwa aktivitas murid kelas IV Sekolah Madrasah Ibtidayah Negeri 2 Makassar dalam media komunikasi visualdapat dikategorikan efektif.

Pengaruh Penggunaan Media Komunikasi Visual Terhadap Hasil Belajar Keterampilan Berbicara pada Mata Pelajaran Aqidah Dan Akhlak Siswa Kelas IV Sekolah Madrasah Ibtidayah Negeri 2 Makassar.

Sesuai dengan hipotesis penelitian yakni "Jika diterapkan metode latihan terbimbing, maka terdapat pengaruh positif dalam hasil belajar Aqidah Dan Akhlaksiswa kelas IV Sekolah Madrasah Ibtidayah Negeri 2 Makassar", maka teknik yang digunakan untuk menguji hipotesis tersebut adalah teknik statistik deskriptif dengan menggunakan uji-t.

Copyright (C2020, JRPD, ISSN 2615 - 1723 (Print), ISSN 2615 - 1766 (Online) 
Jurnal Riset Pendidikan Dasar, 03 (1), April 2020 (63-69)

Darmawati, Nursyaida

Langkah-langkah dalam pengujian hipotesis adalah sebagai berikut:

Mencari harga "Md" dengan menggunakan rumus:

$$
\begin{aligned}
& \text { Md }=\frac{\sum d}{N} \\
& =\frac{425}{28} \\
& =15,18
\end{aligned}
$$

Mencari harga " $\sum X^{2} d$ " dengan menggunakan rumus:

$$
\begin{aligned}
\sum X^{2} d=\sum & d^{2}-\frac{\left(\sum d\right)^{2}}{N}=8.675-\frac{(425)^{2}}{28} \\
& =8.675-\frac{180.625}{28} \\
& =8.675-6450 \\
& =2.225
\end{aligned}
$$

\section{Menentukan harga $\mathbf{t}_{\text {Hitung }}$}

$$
\begin{aligned}
& \mathrm{t}=\frac{M d}{\sqrt{\frac{\sum X^{2} d}{N(N-1)}}} \\
& \mathrm{t}=\frac{15,18}{\sqrt{\frac{2.225}{28(28-1)}}} \\
& \mathrm{t}=\frac{15,18}{\sqrt{\frac{2.225}{756}}} \\
& \mathrm{t}=\frac{15,18}{\sqrt{2,94}}=8,88 \\
& \mathrm{t}=\frac{15,18}{1,71}
\end{aligned}
$$

\section{Menentukan harga $t_{\text {Tabel }}$}

Untuk mencari $t$ Tabel peneliti menggunakan tabel distribusi $t$ dengan taraf signifikan $\alpha=0,05$ dan $d . b=N-1=28-1=27$ maka diperoleh $\mathrm{t}_{0,05}=1,70$.

Setelah diperoleh $\mathrm{t}_{\text {Hitung }}=8,88$ dan $\mathrm{t}_{\text {Tabel }}=$ 1,70 maka diperoleh $t_{\text {Hitung }}>t_{\text {Tabel }}$ atau 8,88> 1,70. Sehingga dapat disimpulkan bahwa penggunaan media komunikasi berpengaruh positif terhadap hasil belajar keterampilan berbicara siswa kelas IV Sekolah Madrasah Ibtidayah Negeri 2 Makassar

\section{SIMPULAN}

Berdasarkan hasil penelitian dan pembahasan disimpulkan bahwa penggunaan media komunikasi visual berpengaruh terhadap hasil belajar keterampilan berbicara pada mata pelajaran Aqidah Dan Akhlak siswa kelas IV Sekolah Madrasah Ibtidayah Negeri 2 Makassar. Hal ini dapat dibuktikan sebelum digunakan media komunikasi visual dikategorikan rendah dengan perolehan persentase hasil belajar siswa dengan kategori sangat rendah yaitu $21,43 \%$, sedang $39,29 \%$, tinggi $14,28 \%$ dan sangat tinggi berada pada persentase $3,57 \%$.

Uji hipotesis penggunaan media komunikasi visual berpengaruh terhadap hasil belajar keterampilan berbicara pada mata pelajaran Aqidah Dan Akhlak siswa kelas IV Sekolah Madrasah Ibtidayah Negeri 2 Makassar setelah diperoleh Md $=15,18, t_{\text {hitung }}=8,88$ dan $t_{\text {tabel }}=1,70$, maka diperoleh $\mathrm{t}_{\text {hitung }}>\mathrm{t}_{\text {tabel }}$ atau $8,88>1,70$.

Berdasarkan temuan yang berkaitan dengan hasil penelitian pengaruh penggunaan media komunikasi terhadap hasil belajar keterampilan berbicara siswa kelas IV Sekolah Madrasah Ibtidayah Negeri 2 Makassar, maka dikemukakan beberapa saran yaitu : 1) Kepada para pendidik, khususnya guru Sekolah Madrasah Ibtidayah Negeri 2 Makassardisarankan untuk menggunakan media komunikasi yang baik untuk membuat siswa lebih aktiv serta membangkitkan minat dan motivasi siswa untuk belajar. 2) Kepada peneliti, diharapkan mampu mengembangkan penggunaan media komunikasi yang baik dengan menerapkan pada materi lain untuk mengetahui apakah pada materi lain cocok dengan metode pembelajaran ini demi tercapainya tujuan yang diharapkan. 3) Kepada calon peneliti, akan dapat mengembangkan dan memperkuat penggunaan media komunikasiserta memperkuat hasil penelitian dengan cara mengkaji terlebih dahulu dan mampu mengadakan penelitian yang lebih sukses.

\section{UCAPAN TERIMA KASIH}

Rasa hormat dan Ucapan terima kasih disampaikan kepada Sekolah Madrasah Ibtidayah Negeri 2 Makassar atas kerjasamanya melakukan penelitian selama satu bulan mulai 05 Mei sampai 05 Juni 2018.Dan terima kasih kepada semua pihak

Copyright $@ 2020$, JRPD, ISSN 2615 - 1723 (Print), ISSN 2615 - 1766 (Online) 
Jurnal Riset Pendidikan Dasar, 03 (1), April 2020 (63-69)

Darmawati, Nursyaida

yang telah membantu selama penelitian ini dilakukan.

\section{DAFTAR PUSTAKA}

Afhdal, F.A. (2003). Dasar-Dasar Pelayanan Prima.Jakarta: Elex Media Komputindo.

Arikunto, S. (2010). Prosedur Penelitian Suatu Pendekatan Praktik. Jakarta: Rineka Cipta.

Arikunto, S. (2010).Dasar-Dasar Evaluasi Pendidikan. Jakarta: Bumi Aksara

Arikunto,S. (2010).Manajemen Penelitian.Jakarta: Rineka Cipta.

Djamarah, B.S. (2011). Psikologi Belajar. Jakarta: Pt. Rineka Cipta.

Hamalik, O.(2009). Psikologi Belajar dan Mengajar. Bandung. Pt Sinar Baru Algensindo.

Ibrahim., \& Sudjana, N.(2004). Penelitian dan Penilaian Pendidikan. Bandung: Sinar Baru Alesindo.

Irianto, A. (2004). Statistik Konsep Dasar dan Aplikasinya. Jakarta: KencanaPrenada Media Group.

Margono. (2004). Metodologi Penelitian Pendidikan. Jakarta: Rineka Cipta.

Mustofa, A \& Muhammad. (2011). Belajar dan Pembelajaran. Yogyakarta: Ar-Ruzz Media

Purwanto, N. (2007). Psikologi Pendidikan.Bandung; Pt. Rosda Karya.

Santoso, G. (2005). Metode Peneletian Kuantitatif dan Kualitatif. Jakarta: Prestasi Pustaka.

Subana. (2000). Statistic Pendidikan. Bandung: Pustaka Setia.

Sudjana, N.(2013). Penilaian Hasil Belajar Mengajar. Bandung: Remaja Rosdakarya.

Sukardi. (2003). Metodologi Penelitian Pendidikan. Jakarta: Bumi Aksara.

Supranto. (2007). Teknik Sampling untuk Survey dan Eksperimen. Jakarta: Rineka Cipta.

Sutanli, M. (2010). Strategi Pengajaran Bahasa dan Sastra Indonesia. Jakarta: Tema Pustaka.

Tanzeh, A. (2009). Pengantar Metodologi Penelitian. Yogyakarta: Teras.

Copyright $@ 2020$, JRPD, ISSN 2615 - 1723 (Print), ISSN 2615 - 1766 (Online) 